\title{
The role of bone morphogenetic proteins 2, 4, 6 and 7 during ovarian follicular development in sheep: contrast to rat
}

\author{
Jennifer L Juengel ${ }^{1}$, Karen L Reader ${ }^{1}$, Adrian H Bibby ${ }^{1}$, Stan Lun ${ }^{1}$, Ian Ross ${ }^{2}$, Lisa J Haydon ${ }^{1}$ \\ and Kenneth P McNatty ${ }^{1}$ \\ ${ }^{1}$ AgResearch, Wallaceville Animal Research Centre, Ward Street, PO Box 40063, Upper Hutt, New Zealand, \\ ${ }^{2}$ AgResearch Molecular Biology Unit, Department of Biochemistry, University of Otago, Dunedin, New Zealand
}

Correspondence should be addressed to J Juengel; Email: jenny.juengel@agresearch.co.nz

\begin{abstract}
The intraovarian roles of BMP family members such as BMP2, 4, 6 and 7 are not well understood, particularly in species with low ovulation rates such as sheep. Therefore, the objectives of these experiments were to determine the expression patterns of mRNAs encoding BMP2, 4, 6 and 7 during ovarian follicular development in sheep, and to determine the effects of these growth factors on ovine granulosa cell functions in vitro. For comparative purposes, the effects of these BMPs were also determined in rat granulosa cells since these factors have been most widely studied in this poly-ovulatory species. As assessed by in situ hybridization, non-atretic ovine follicles expressed mRNA for BMP6 but not 2, 4 or 7. Furthermore, expression of BMP6 was limited to the oocyte of primordial as well as primary, pre-antral and antral follicles. Reverse transcription-PCR of granulosa cell mRNA detected low levels of all the BMPs in some pools of cells. BMP2, 4, 6 and 7 each inhibited progesterone production from ovine granulosa cells without affecting cellular proliferation/survival. Similarly, these BMPs inhibited progesterone production from rat granulosa cells. However, they also stimulated cellular proliferation/survival of the rat granulosa cells highlighting a species-specific difference for these growth factors. In conclusion, in sheep, BMP2, 4, 6 and 7 inhibit granulosa cell differentiation without affecting proliferation. However, as BMP2, 4 and 7 were not detectable by in situ hybridization in any cells of non-atretic ovarian follicles, it seems unlikely that these proteins would have an important intraovarian role in regulating follicular development in sheep. In contrast, localization of BMP6 mRNA in the oocyte suggests that this BMP family member may have a paracrine and/or autocrine role in regulating follicular growth in sheep, as has been shown for two other oocyte derived from members of the transforming growth factor superfamily, BMP15 and growth differentiation factor 9.

Reproduction (2006) 131 501-513
\end{abstract}

\section{Introduction}

The transforming growth factor $\beta$ (TGF- $\beta$ ) superfamily, which includes growth differentiation factors (GDF), bone morphogenetic proteins (BMP), TGF- $\beta$, and activin/inhibin subfamilies as well as proteins, such as anti-mullerian hormone, is comprised of over 35 proteins with common structural motifs (Chang et al. 2002). It is known that several members of this superfamily are important regulators of ovarian follicular growth and development in many species (Matzuk 2000, Kaivo-Oja et al. 2003, Knight \& Glister 2003, McNatty et al. 2003, Shimasaki et al. 2004). However, the precise roles that members of this family play, appear to differ between species. For example, BMP15 (also known as GDF9b) has been shown to be essential for normal follicular growth and fertility in sheep and humans (Galloway et al. 2000, Juengel et al. 2002, Di Pasquale et al. 2004, Hanrahan et al. 2004), whereas mice lacking BMP15 are fertile (Yan et al. 2001). In addition, while BMP15 and GDF9 have each been shown to be essential for regulating ovulation rate in sheep (Davis et al. 1991, Galloway et al. 2000, Hanrahan et al. 2004, Juengel et al. 2004), no such role has been clearly demonstrated for either factor in mice (Dong et al. 1996, Yan et al. 2001). Species differences also appear to exist in the potential roles of TGF- $\beta 1-3$ as well as in their ovarian cellular origins (Juengel \& McNatty 2005).

The BMP subfamily members, BMP2, 4, 6 and 7 have been shown to be expressed by follicular cells in several species such as mice, rats, chickens and cows (Shimasaki et al. 1999, Erickson \& Shimasaki 2003, Onagbesan et al. 2003, Glister et al. 2004) and furthermore, to regulate follicular cell function in vitro (Shimasaki et al. 1999, Dooley et al. 2000, Lee et al. 2001, Mulsant et al. 2001, Otsuka et al. 2001, Souza et al. 2002, Fabre et al. 2003, 
Onagbesan et al. 2003, Nilsson \& Skinner 2003, Glister et al. 2004, 2005, Lee et al. 2004, Pierre et al. 2004). While it is known that follicular cells in sheep express receptors capable of responding to these BMPs (Wilson et al. 2001, Souza et al. 2002) and that BMP2 and 4 can regulate granulosa cell function (Mulsant et al. 2001, Souza et al. 2002, Fabre et al. 2003, Pierre et al. 2004) the ovarian cell-types that express BMP2, 4, 6 and 7, as well as the effects of BMP6 and BMP7 on granulosa cell function are presently unknown in sheep. Given the importance of BMP15 and GDF9 in regulation of follicular growth and ovulation rate as well as the known effect of mutations in the BMPRIB gene on ovarian activity in sheep (Shimasaki et al. 2004, McNatty et al. 2005a), the characterization of the ovarian cell-types that produce other BMP family members as well as the effects of these proteins on granulosa cell function is central to further elucidation of their roles in regulating ovarian activity. The objectives of this study were to determine the patterns of expression of BMP2, 4, 6 and 7 in the ovine ovary and to determine the effects of these ligands on ovine granulosa cell proliferation and progesterone production. In addition, we determined the role of these BMPs in rat granulosa cells under identical culture conditions to be able to compare more directly the effects of BMPs on granulosa cells of sheep and the more extensively studied species, the rat.

\section{Materials and methods \\ Collection of tissue samples}

All experiments were performed in accordance with the 1999 Animal Welfare Act Regulations of New Zealand. All animals had access to pasture and water, and were allowed to feed ad libitum. Lambs were kept with their mothers until just prior to tissue collection. Romney ewes and lambs were killed by administration of a barbiturate overdose (pentobarbitone; $200 \mathrm{mg} / \mathrm{kg}$ ) or by captive bolt.

\section{Cloning of BMP2, 4, 6 and 7 and in situ hybridization}

Except where indicated, laboratory reagents were obtained from BDH Chemicals New Zealand Ltd (Palmerston North, New Zealand), Invitrogen (Auckland, New Zealand) or Roche Diagnostics N.Z. Ltd (Auckland, New Zealand).
Complimentary cDNAs encoding a portion of ovine BMP2, 4, 6 and 7 were generated using standard reverse transcription(RT)-PCR techniques. Primers and conditions for PCR are listed in Table 1. Sequences of resulting plasmids were confirmed prior to use for in situ hybridization. In situ hybridization was performed as previously described (Tisdall et al. 1999) with minor modifications. Briefly, 4-6 $\mu \mathrm{m}$ tissue sections were incubated overnight at $\quad 50-55^{\circ} \mathrm{C}$ with 45000 c.p.m./ $\mu$ l (approximately 48000 d.p.m./ $\mu \mathrm{l}$ ) of ${ }^{33}$ P-labelled antisense RNA. Nonspecific hybridization of RNA was removed by RNase A digestion followed by stringent washes $(2 \times$ SSC, $50 \%$ formamide, $65^{\circ} \mathrm{C}$ and $0.2 \times \mathrm{SSC}$ at $37^{\circ} \mathrm{C}$ ). Following washing, sections were dehydrated, air dried and coated with autoradiographic emulsion (LM-1 emulsion; Amersham Pharmacia Biotech New Zealand). Emulsion-coated slides were exposed at $4{ }^{\circ} \mathrm{C}$ for 3-4 weeks, developed for $3.5 \mathrm{~min}$ in D19 developer (Eastman Kodak, Rochester, NY, USA). Development was stopped using a $1 \mathrm{~min}$ incubation in $1 \%$ acetic acid and slides were fixed with a 10 min incubation in Ilfofix II (Ilford Limited, Cheshire, England). Sections were stained with hematoxylin and then viewed and photographed using both light and dark field illumination on an Olympus BX-50 microscope (Olympus New Zealand Ltd). At least 8 animals were examined for expression of each of the BMP genes. These included both lambs and adult ewes and no differences were noted in the pattern of gene expression related to the age of the animal. In addition, as the expression of BMP4 and 7 was not commonly observed in the ovarian sections, a positive control tissue of fetal kidney $(n=2)$ was included with each in situ hydridization. This tissue had been collected from female ovine fetuses collected on day 40 of gestation, which were part of another approved study. Follicles at each defined stage of development were observed in at least 3 animals for all genes examined. Classification of follicles at each developmental stage was based on the system outlined (Lundy et al. 1999). Briefly, type 1/1a follicles consist of an oocyte surrounded by a single layer of flattened or mixed flattened and cuboidal cells. Type 2 follicles contain $1<2$ layers of cuboidal granulosa cells, whereas type 3 follicles contain $2<4$ layers of cuboidal granulosa cells. Type 4 follicles have $>4$ layers of granulosa cells and a well defined theca, but have not yet formed an antrum. Type 5 follicles have multiple layers of granulosa cells, a well defined theca and a defined antrum. All follicles with signs

Table 1 Primers used for PCR, resulting product size, annealing temperature used in PCR reaction and the reference number of the resulting sequence for the ovine bone morphogenetic proteins (BMP) 2, 4, 6 and 7 .

\begin{tabular}{|c|c|c|c|c|c|}
\hline Gene & $\begin{array}{l}\text { Forward Primer } \\
\left(5^{\prime}-3^{\prime}\right)\end{array}$ & $\begin{array}{l}\text { Reverse Primer } \\
\left(5^{\prime}-3^{\prime}\right)\end{array}$ & $\begin{array}{l}\text { Product size } \\
\text { (bp) }\end{array}$ & $\begin{array}{l}\text { Annealing temperature } \\
\qquad\left({ }^{\circ} \mathrm{C}\right)\end{array}$ & $\begin{array}{l}\text { Genbank number } \\
\text { (Resulting sequence) }\end{array}$ \\
\hline BMP2 & $\begin{array}{l}\text { gagaaaccatggaagcaaaacacaaacagcgg } \\
\text { (includes Nco I site) }\end{array}$ & $\begin{array}{l}\text { gtgagatctacacccacaaccctcgacaac } \\
\text { (includes Bglll site) }\end{array}$ & 353 & 58 & DQ192012 \\
\hline BMP4 & catcacacgactactggac & cctctactacgatctcctg & 627 & 50 & DQ192013 \\
\hline BMP6 & cagcgcctcagactactacaac & caaccacacgctcgtacg & 342 & 58 & DQ192014 \\
\hline BMP7 & ctccagggcaagcacaac & gttgatgctctgtccgtcc & 561 & 50 & DQ192015 \\
\hline
\end{tabular}


of degeneration (i.e. pyknotic granulosa cells, lack of a distinct basement membrane or degenerate oocytes) were considered atretic. Non-specific hybridization was monitored by hybridizing the sense RNA for each receptor to tissue collected from at least one animal per age group. Hybridization was considered specific when the intensity of silver grains, as measured by visual assessment, over a cellular type was greater than that observed in the area of the slide not containing tissue. For all genes, hybridization of the sense RNA over the tissue section was similar or lower in intensity to that observed on the areas of the slide not containing tissue of both the sense and antisense hybridized slides and thus was considered non-specific.

\section{Determination of expression of BMP mRNAs in freshly isolated granulosa cells}

Granulosa cells were isolated from follicles 1-2 mm in diameter from ovine ovaries collected from the local abattoir. Follicles lacking vascularity or with debris in their follicular fluid were considered atretic and discarded. Granulosa cells were only used from follicles in which the oocyte was localized and removed. Three pools of granulosa cells were generated. All cells from each follicle and all follicles from each ovary were placed in a single pool of cells. RNA was collected using TRIzol according to the manufacturer's instructions. First strand cDNA was produced from DNase treated total cellular RNA using the SuperScript preamplification system for first strand cDNA synthesis. Effeciency of cDNA synthesis was analyzed using primers specific for follistatin, which is highly expressed in ovine ovarian tissue and granulosa cells (Tisdall et al. 1994). These primers (CTGGAAATTGCTGGCTCC and AGTCCTGGTCTTCATCTTC) are located in two separate exons of the follistatin gene. Expression of the different BMPs were determined by PCR using the following ovine primers (BMP2 CAGAACTTCAGGTCTTCGG and GCACTGAGCTCTGTTGGG; BMP4 TAACCGAATGCTGATGGTCG and CCTTGTCATACTCATCCAGG; BMP6 AGCGAGCTGAAGACGGCC and ATGTTCCTATACTTCTTCAGG; BMP7 CCTATCCCTACAAGGCCG and CTGTCGAGCAGGAACAGG). All PCRs were carried out using HotMaster Taq (Eppendorf) with the following conditions: initial denaturing cycle of $2 \mathrm{~min}$ at $94^{\circ} \mathrm{C}$ followed by 40 cycles of denaturing at $94^{\circ} \mathrm{C}$ for $20 \mathrm{~s}$, annealing at $58^{\circ} \mathrm{C}$ for $15 \mathrm{~s}$ and extension at $72^{\circ} \mathrm{C}$ for $50 \mathrm{~s}$ and a final extension at $72^{\circ} \mathrm{C}$ for $10 \mathrm{~min}$. CDNA generated from a 4 week old lamb ovary, which contains many healthy preantral and antral follicles, was run as a positive control whereas replacement of cDNA with water was used as a negative control. Expression of BMP mRNAs was assessed by visualization of DNA bands of the correct size following gel electrophoresis. Identity of product (from positive control sample) was confirmed by sequencing.

\section{Granulosa cell culture}

Collection of granulosa cells

Granulosa cells were isolated from 1-2 $\mathrm{mm}$ follicles from ovine ovaries collected from the local abattoir and from Sprague-Dawley rats (23-26 day old; University of Otago, Dunedin, New Zealand). Granulosa cells were also collected from sheep and rats approximately $96 \mathrm{~h}$ after subcutaneous administration of implants containing diethylstilbestrol (DES). Rats received a single implant of approximately $1.8 \mathrm{~cm}$ with an internal diameter of $3.35 \mathrm{~mm}$ (Chen et al. 2001). Ewes received 2 implants based on previous results with implants containing oestradiol (McNatty et al. 1989). Oocytes and follicular debris were removed from the cells using a micro-glass pipette. Remaining cells were collected by centrifugation at $300 \mathrm{~g}$ for $5 \mathrm{~min}$ at room temperature, washed once in $5 \mathrm{ml}$ Leibovitz media, twice in $5 \mathrm{ml}$ McCoys media (Sigma, Auckland, New Zealand) and resuspended using a syringe and needle. Cell viability was determined using trypan blue exclusion, 100000 viable cells per well $(250 \mu$ l total volume) were added in McCoys media containing $100 \mathrm{U} / \mathrm{ml}$ penicillin, $100 \mu \mathrm{g} / \mathrm{ml}$ streptomycin, $2 \mathrm{mM}$ GlutaMAX- 1 and $0.1 \%$ BSA. Media for cells used for progesterone and DNA determination also contained $5 \mathrm{ng} / \mathrm{ml}$ selenium (Sigma), $10 \mathrm{ng} / \mathrm{ml}$ insulin (Sigma), $5 \mu \mathrm{g} / \mathrm{ml}$ apotransferrin (Sigma), $30 \mathrm{ng} / \mathrm{ml}$ androstenedione (Sigma), $3 \mathrm{ng} / \mathrm{ml}$ ovine FSH (purified in our laboratory; $1.4 \mathrm{X}$ USDA-oFSH-19-SIAFP RP2), and 1 ng/ml IGF-1 (Long-R3, GroPep, Adelaide, SA, Australia).

\section{Determination of ${ }^{3} \mathrm{H}$-thymidine incorporation}

Cells (100000 viable cells per well) were incubated in media described above with the addition of $6{ }^{3} \mathrm{H}$-thymidine (Perkin Elmer, Boston, MA, $20 \mathrm{Ci} / \mathrm{mmol}, 1.0 \mu \mathrm{Ci}$ per well) with or without human (h) BMP2, hBMP4, hBMP6 or hBMP7 ( $3 \mu \mathrm{g} / \mathrm{ml}$; R\&D Systems Inc, MN USA) for $48 \mathrm{~h}$ at $37^{\circ} \mathrm{C}$ in a $5 \% \mathrm{CO}_{2}$ incubator. This standardized dose of BMP added to the cultures was chosen after analysis of dose-response assays with both sheep and rat granulosa cells (see Fig. 1 for representative data from sheep). At the termination of culture, cells were harvested with a cell harvester onto a thick filter mat. Incorporation of ${ }^{3} \mathrm{H}$-thymidine was determined using a Wallac Trilux MicroBeta 1450 liquid scintillation counter (Biolab, Auckland, New Zealand). Average values for incorporation of ${ }^{3} \mathrm{H}$-thymidine were determined for each treatment, outlier replicates (outside of $30 \%$ of the mean) were identified and discarded.

\section{Determination of progesterone and DNA content}

Cells were cultured at $37{ }^{\circ} \mathrm{C}$ in a $5 \% \mathrm{CO}_{2}$ incubator in media specified above with or without $300 \mathrm{ng} / \mathrm{ml}$ of hBMP2, hBMP4, hBMP6, or hBMP7 for 6 days. The BMP dose of $300 \mathrm{ng} / \mathrm{ml}$ was also chosen for these studies following analysis of preliminary dose-response studies 
(see Fig. 1 for representative data from sheep). Every $48 \mathrm{~h}$, $200 \mu \mathrm{l}$ of media was removed from each well and replaced with $200 \mu$ l of warmed media that had been prepared at the start of the culture and stored at $4{ }^{\circ} \mathrm{C}$. Media samples from the first (rat only) and last $48 \mathrm{~h}$ of treatment were collected on the appropriate day of treatment and frozen at $-20^{\circ} \mathrm{C}$ for later determination of progesterone concentrations by RIA. Unattached cells were removed by 2 washes with McCoys media at $37^{\circ} \mathrm{C}$. Attached cells were lysed by incubating cells at $37^{\circ} \mathrm{C}$ in $100 \mu$ l distilled water for $1-2 \mathrm{~h}$ followed by freezing at $-70^{\circ} \mathrm{C}$.

\section{Measurement of progesterone}

Concentrations of progesterone in media were determined by RIA as described (Lun et al. 1998). The sensitivity of the assay (90\% maximum binding) was $16 \mathrm{pg} / \mathrm{ml}$ and the intra- and interassay co-efficients of variation (CV), averaged for a standard pool sample at approximately 20, 50 and $80 \%$ binding, was 11 and $16 \%$, respectively. No samples were below the sensitivity of the assay. Average values for progesterone concentrations were determined

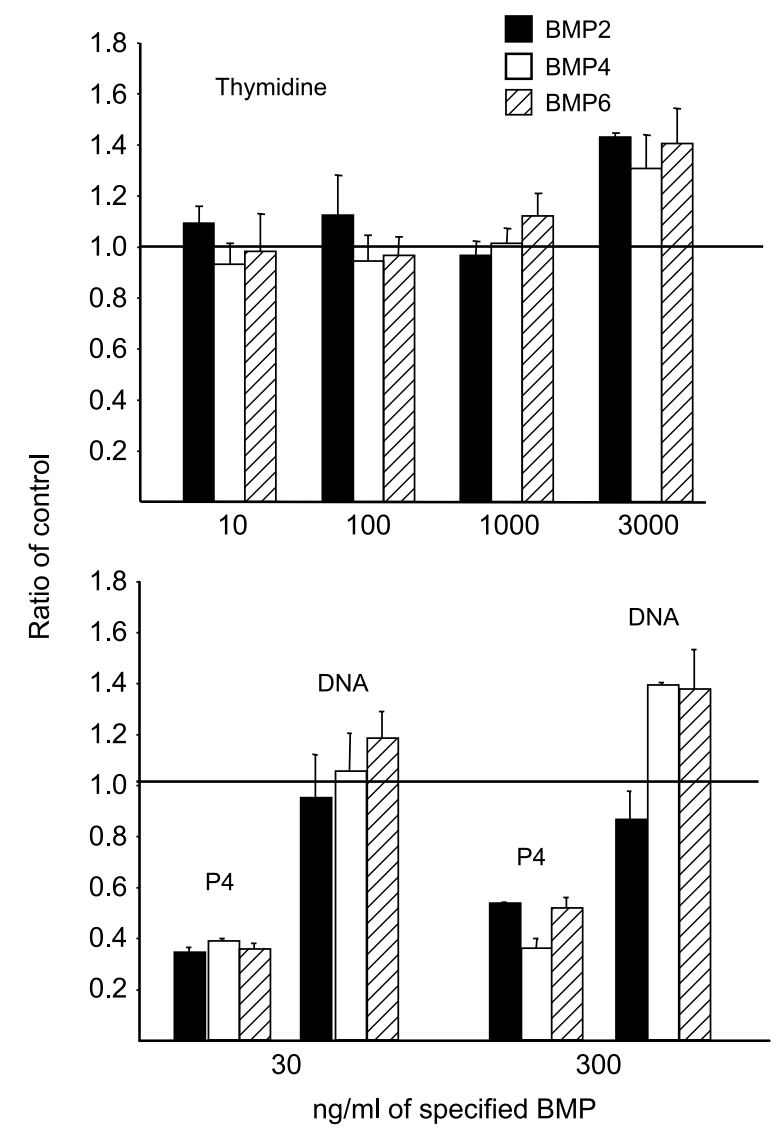

Figure 1 Effects of varying doses of bone morphogenetic protein (BMP) 2, 4 and 6 on thymidine uptake (top panel) and progesterone and DNA concentrations (bottom panel). Granulosa cells were collected from sheep not treated with DES. Values (mean+S.E.M. of replicate wells of a single pool of granulosa cells) are expressed as a ratio of the control value, which is indicated with the horizontal line at 1.0. for each treatment within each independent granulosa cell bioassay, outlier replicates (outside of $20 \%$ of the mean) were identified and discarded.

\section{Measurement of DNA}

The amount of DNA present in each well was determined by comparing binding of Hoechst 33258 dye (Sigma, final concentration of $10 \mu \mathrm{g} / \mathrm{ml}$ in well) in samples to calf thymus DNA standard measured with a Wallac 1420 plate reader at $350 \mathrm{~nm}$ for excitation and $460 \mathrm{~nm}$ for emission. Sensitivity of the assay ( + two S.D. of control buffer value) was $20 \mathrm{ng}$ per well and the intra- and interassay $\mathrm{CV}$, based on variability of the 100, 250, 1000 and $2500 \mathrm{ng}$ standard curve points were 6 and $6 \%$, respectively. No samples were below the sensitivity of the assay.

\section{Statistical analysis}

Amount of progesterone produced per $\mu \mathrm{g}$ DNA was calculated individually for each well. Replicates that were not within $30 \%$ of the mean were discarded. For each variable, effects of specified treatment were determined by comparison to the untreated control sample using the 2 -tailed paired $t$-test function in Microsoft Excel 2003. As the BMPs were not always run in the same assay, no statistical comparisons were made between the effects of the various BMPs. For ease of presentation, all values have been converted to a ratio of the appropriate controls which were assigned a value of 1.00 .

\section{Results}

\section{Expression of BMP2, 4, 6 and 7 as assessed by in situ hybridization}

\section{BMP2}

Expression of mRNA encoding BMP2 was not observed in the granulosa cells, thecal cells, cumulus cells or oocytes of non-atretic follicles of any size class (Fig. 2). Atretic type 5 follicles expressed BMP2 mRNA in the degenerating granulosa cells and this was most pronounced in follicles in the late stages of atresia (Fig. 2).

\section{BMP4}

BMP4 mRNA was not evident in granulosa cell, theca interna, cumulus cells or oocytes of non-atretic follicles of any size examined (Fig. 3). Expression of BMP4 mRNA was often observed in the surface epithelium and around blood vessels. In addition, expression was observed in a concentric circle around some antral follicles. This expression did not appear to be in the theca interna or externa of these follicles although the boundary between the theca externa and stromal cells of the ovary can be difficult to discern. Often, these follicles were atretic. The positive controls (i.e. sections of kidney tissue collected on day 40 of fetal life) expressed mRNA encoding BMP4 (Fig. 3). 


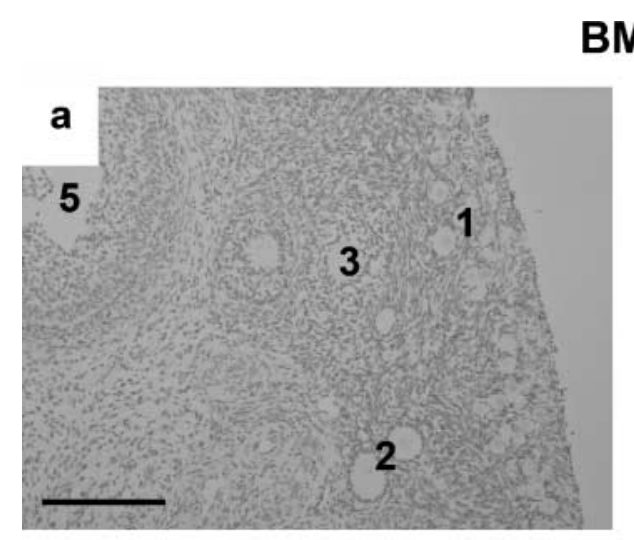

BMP2
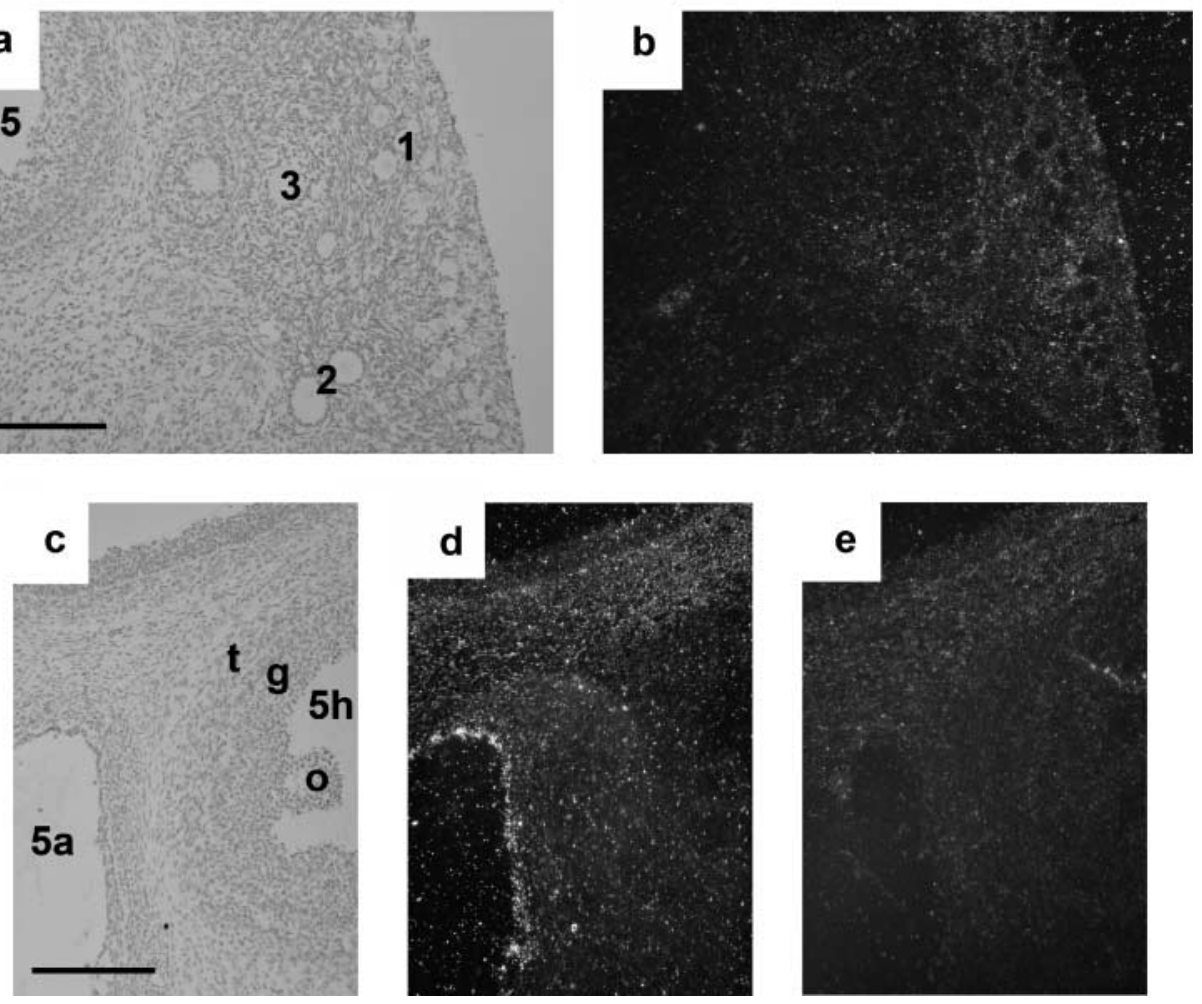

Figure 2 Corresponding bright field ( $a, c)$ and dark field (b, d, e) views of ovaries collected from 4 week old lambs following hybridization to BMP2 antisense (a-d) or sense (e) RNA. (a, b) No specific signal is observed in the healthy type 1, 2, 3 or 5 follicles. (c, d) Signal can be observed in the atretic type 5 follicle (5a) but is not observed in the healthy type 5 follicles $(5 \mathrm{~h}$ ). (e) No specific signal was observed when the sense RNA was hybridized to the follicles shown in panels c and d. Scale bar equals approximately $200 \mu \mathrm{m}$ for all panels. o, oocyte; $\mathrm{g}$, granulosa; $\mathrm{t}$, theca.

\section{BMP6}

Oocytes of all sizes of follicles that were examined expressed mRNA encoding BMP6 (Fig. 4). BMP6 mRNA was not evident in either the granulosa or thecal cells of follicles of any size (Fig. 4).

\section{$B M P 7$}

Expression of BMP7 mRNA was not observed in the granulosa cells, thecal cells, cumulus cells or oocytes of healthy follicles of any sized examined (Fig. 5). When rete tubules were present on the slide $(n=3)$, positive expression of BMP7 mRNA was noted. The positive controls (i.e. sections of kidney tissue collected on day 40 of fetal life) expressed mRNA encoding BMP7 (Fig. 5).

\section{Expression of BMPs in isolated granulosa cells as assessed by RT-PCR}

Expression of BMP2, 4, 6 or 7 was observed in at least some pools of granulosa cells (Fig. 6). However, in all cases, the strength of the signal was weak compared with the positive control sample.

\section{Effects of BMPs on granulosa cell cultures}

Sheep

\section{Without DES}

Overall, the effects of BMP2, 4, 6 and 7 were similar. None of these BMPs affected cellular proliferation (Fig. 7) as assessed either over the first $48 \mathrm{~h}$ of culture by thymidine incorporation or during the longer term ( 6 days) through direct measurement of DNA. In contrast, to the lack of effect observed on cellular proliferation, concentrations of progesterone in media were decreased when compared with control cultures following treatment of granulosa cells with either BMP2, 4, 6 or 7 . When the effects of the BMPs were assessed on a per cell basis, concentrations of progesterone/ng DNA were decreased in granulosa cells treated with BMP4, 6 or 7 when compared with control cultures (Fig. 8).

\section{With DES}

Similar to the effects observed on granulosa cells that had not been exposed to DES, none of the BMPs affected proliferation of DES treated ovine granulosa cells (Fig. 7). 

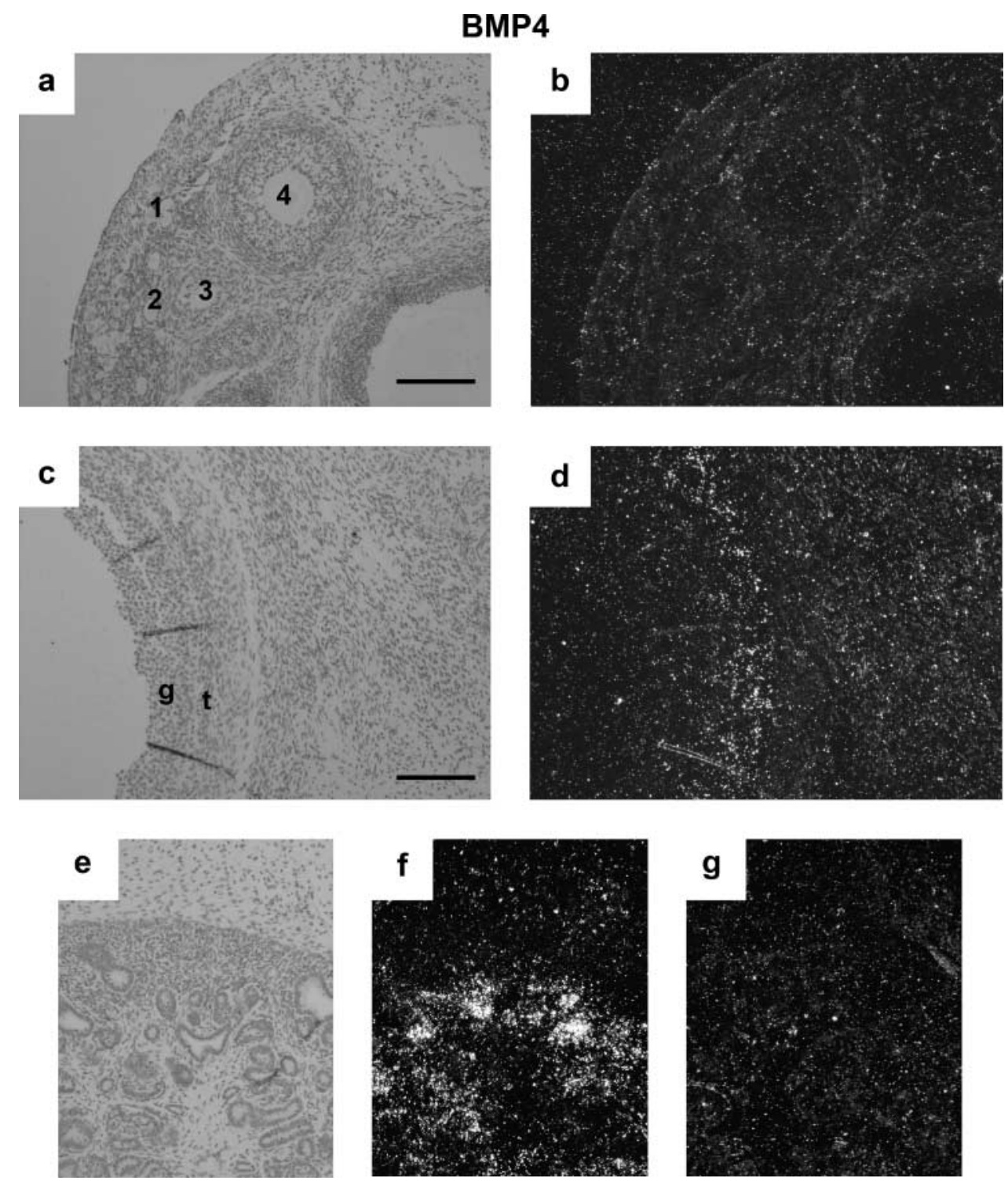

Figure 3 Corresponding bright field (a, c, e) and dark field (b, d, f, g) views of ovaries collected from 4 week old lambs (a, b), adult ewes (c, d) or kidney collected on day 40 of gestation $(\mathrm{e}-\mathrm{g})$ following hybridization to BMP4 antisense (a-f) or sense (g) RNA. (a, b) No specific signal is observed in the healthy type 1, 2, 3 or 4 follicles. (c, d) A healthy type 5 follicle with signal observed in stroma cells just outside the theca layer of the follicle (g, granulosa; $t$, theca). (e, f) Positive expression is also observed in the tubules of the developing kidney. (g) No specific signal was observed when the sense RNA was hybridized to the kidney shown in panels e and f. Scale bar equals approximately $200 \mu \mathrm{m}$ for all panels.

However, the concentrations of progesterone in media were decreased by all BMPs and a similar trend $(P<0.10)$ was observed when progesterone was expressed on a per cell basis (Fig. 8).

\section{Rat}

\section{Without DES}

Treatment of rat granulosa cells with either BMP4, 6 or 7 , but not BMP2, resulted in an increased thymidine uptake over the first $48 \mathrm{~h}$ of culture (Fig. 9). The amount of DNA at the end of culture was not significantly higher than observed for control cultures, although the absolute values were increased between 40-60\% (Fig. 9). All BMPs reduced progesterone concentrations after 2 days in culture and progesterone produced per cell at 6 days in culture (Fig. 10).

\section{With DES}

Treatment of DES-exposed rat granulosa cells with BMP4 resulted in an increased thymidine uptake over the first $48 \mathrm{~h}$ of culture and BMP4, 6 and 7 all increased DNA concentrations following 6 days of culture (Fig. 9). BMP2 had 


\section{BMP6}
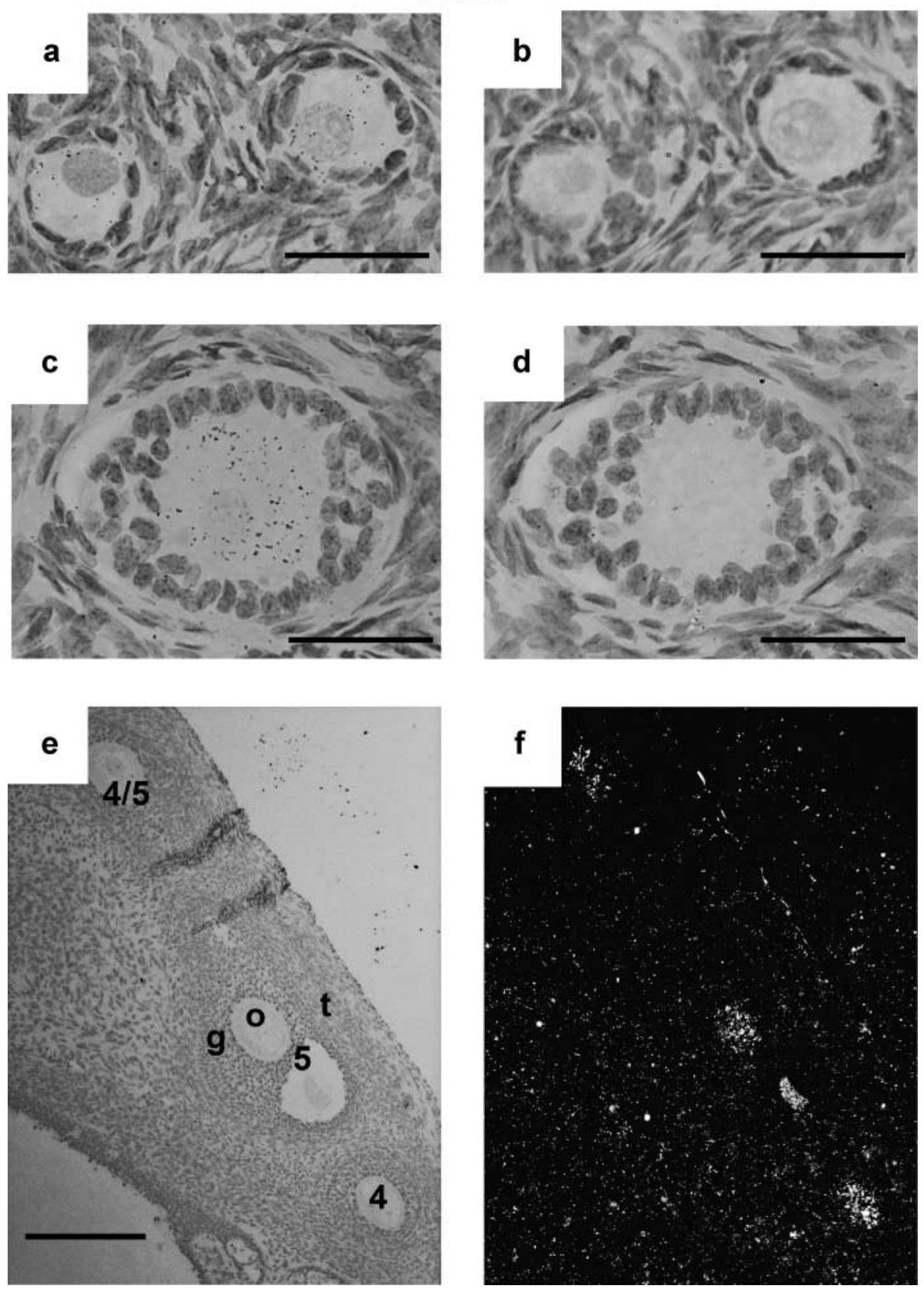

Figure 4 Corresponding bright field (a-e) and dark field ( $f$ ) views of ovaries collected from an adult ewe (a-d) or 4 week-old lamb (e-f) following hybridization to BMP6 antisense (a, c, e, f) or sense (b, d) RNA. (a, c) Silver grains can be observed specifically in the oocyte of the type 1/1a (a) and type 2 (c) follicles. (b, d) No silver grains are observed over the type 1/1a or type 2 follicles in the negative control sense hybridized slides. (e, f) Healthy type 4 and 5 follicles with signal observed in oocytes (o) of the follicles but not in granulosa (g) or theca (t) of the follicles. Scale bar equals approximately $50 \mu \mathrm{m}$ for panels $\mathrm{a}-\mathrm{d}$ and $200 \mu \mathrm{m}$ for panels e and $\mathrm{f}$.

no effect on thymidine uptake or DNA concentrations. Concentrations of progesterone in media were decreased in all BMP treated cultures when compared with control cultures following 2 days of culture but only BMP6 showed a decreased concentration of progesterone compared with controls at 6 days of culture (Fig. 10). However, all BMPs tested decreased progesterone synthesis at 6 days of culture when the concentrations of progesterone were expressed relative to DNA concentration (Fig. 10).

\section{Discussion}

As judged by in situ hybridization, BMP6, but not BMP2, 4 or 7 mRNA was expressed in non-atretic growing 


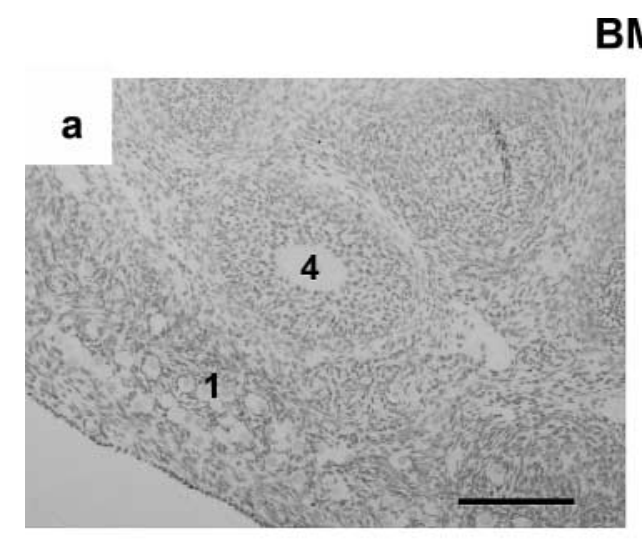

BMP7
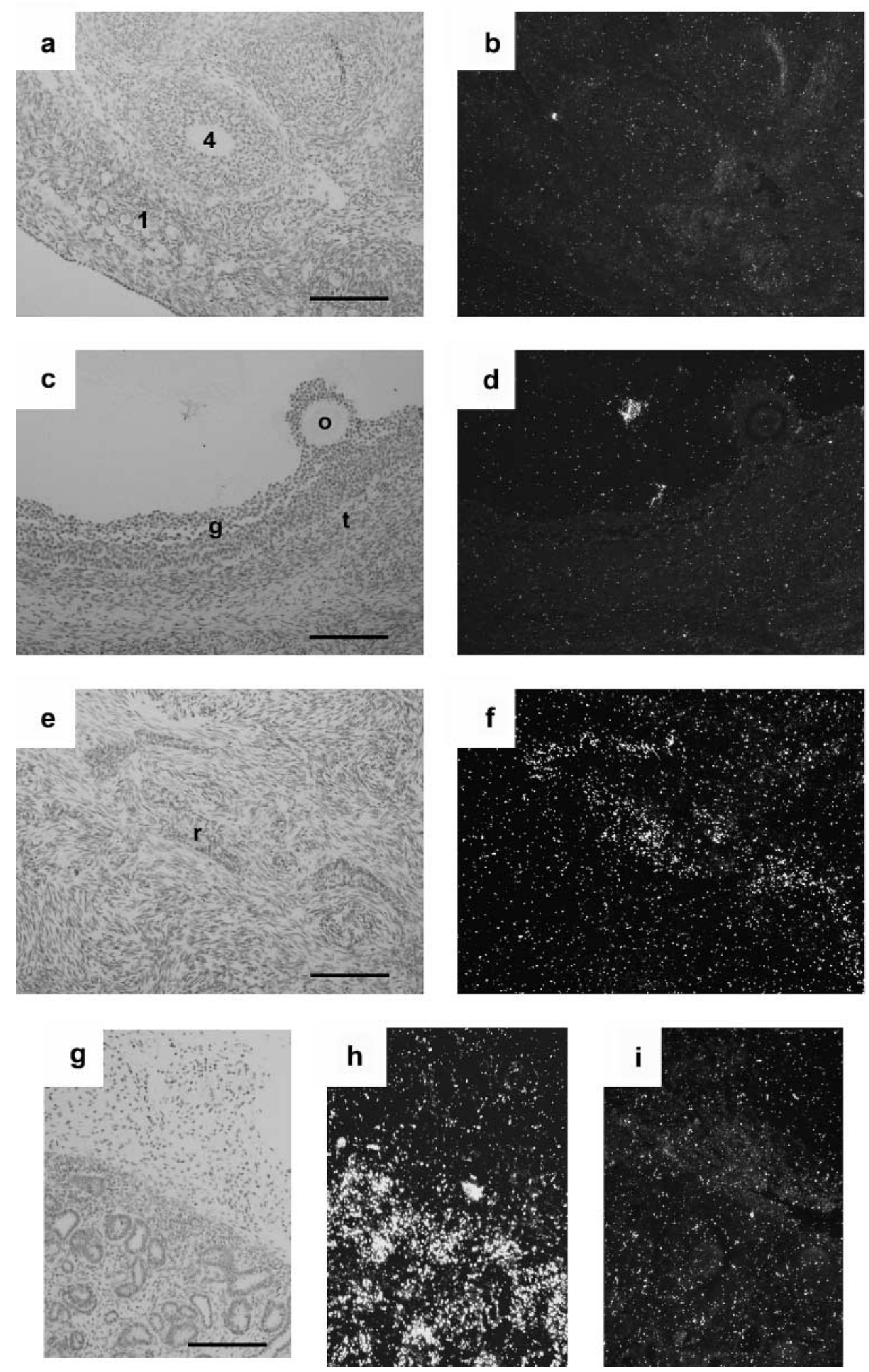

Figure 5 Corresponding bright field ( $a, c, e, g)$ and dark field (b, d, f, h, i) views of ovaries collected from 4 week old lambs ( $a$, b), adult ewes (c-f) or kidney collected on day 40 of gestation (g-i) following hybridization to BMP7 antisense (a-h) or sense (i) RNA. (a, b) No specific signal is observed in the healthy type 1 or 4 follicles. (c, d) A healthy type 5 follicle with no signal observed in the oocyte (o), granulosa (g) or theca (t). $(\mathrm{e}, \mathrm{f})$ Positive expression is observed in the rete $(\mathrm{r}) .(\mathrm{g}, \mathrm{h})$ Positive expression is also observed in the tubules and collecting ducts of the developing kidney. (i) No specific signal was observed when the sense RNA was hybridized to the kidney shown in panels g and h. Scale bar equals approximately $200 \mu \mathrm{m}$ for all panels. 


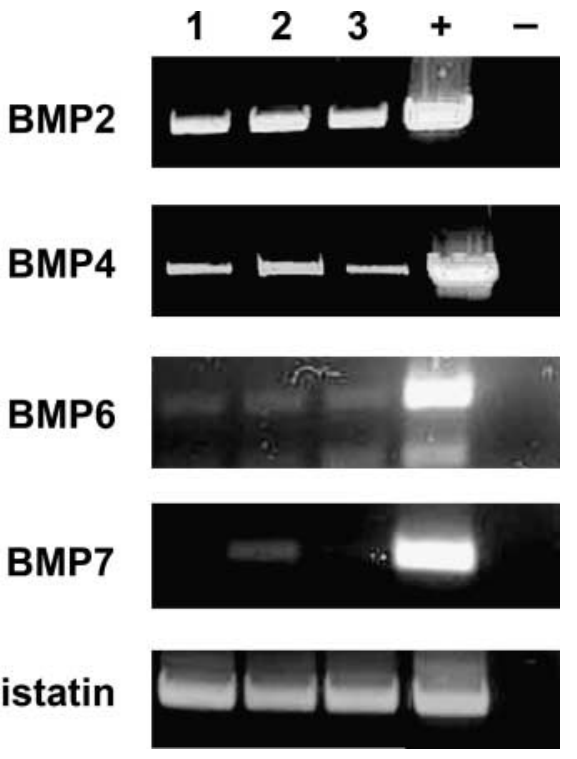

Figure 6 Determination of expression mRNA encoding BMP2, -4, 6 and 7 as assessed by RT-PCR in granulosa cells isolated from nonDES-treated sheep. Lanes 1-3, 3 separate pools of granulosa cells, + positive control sample, - negative control water blank. Identity of BMP product is indicated on the left. Expression of follistatin is indicated at the bottom as a positive control for CDNA synthesis.

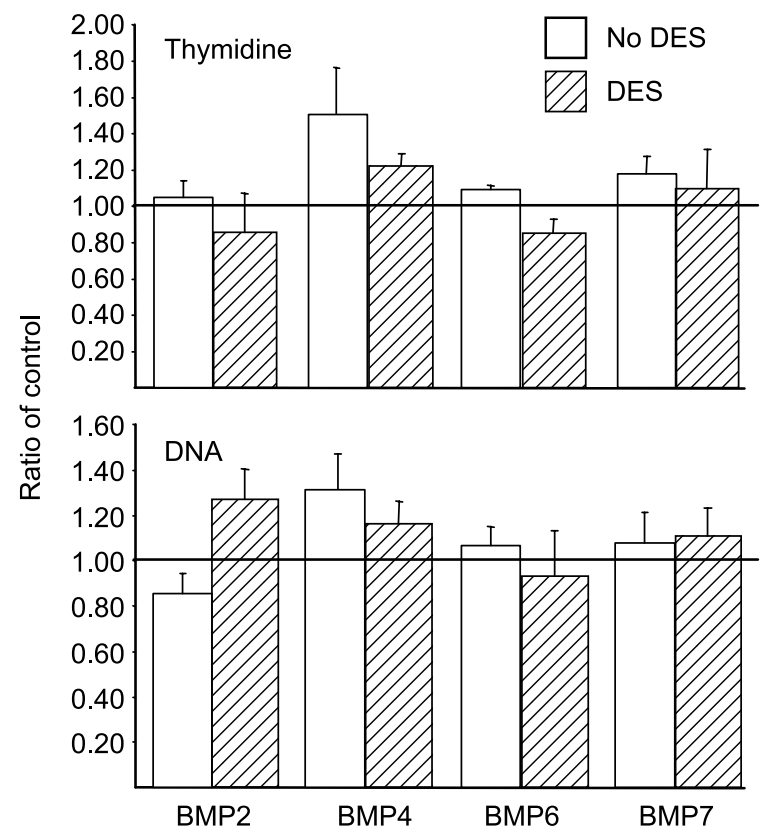

Figure 7 Effects of BMP 2, 4, 6 and 7 on thymidine uptake (top panel) and DNA concentrations (bottom panel). Granulosa cells were collected from sheep not treated with DES (open bar) or sheep treated with DES (striped bar). Values (mean+S.E.M., $n=3-4$ independent pools of granulosa cells) are expressed as a ratio of the control value, which is indicated with the horizontal line at 1.0. None of the treatments had an effect on either thymidine uptake or DNA concentrations $(P>0.05)$.

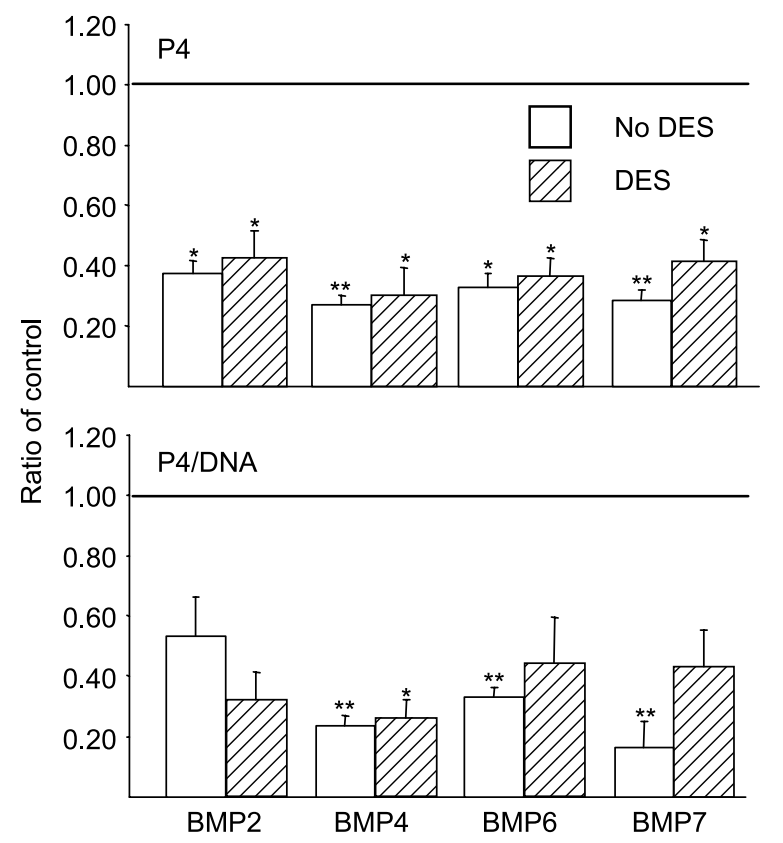

Figure 8 Effects of BMP 2, 4, 6 and 7 on progesterone concentrations in media (top panel) and progesterone concentrations corrected for DNA concentrations (bottom panel). Granulosa cells were collected from sheep not treated with DES (open bar) or sheep treated with DES (striped bar). Values (mean+S.E.M., $n=3-4$ independent pools of granulosa cells) are expressed as a ratio of the control value, which is indicated with the horizontal line at 1.0. ${ }^{*} P<0.05$, ${ }^{* *} P<0.01$ when compared with control values.

follicles. Furthermore, BMP6 mRNA was evident only in the oocyte and was expressed in primordial as well as primary, pre-antral and antral follicles. Using RT-PCR, message for all BMPs were detected in at least some pools of granulosa cells. The detection of these mRNAs by RT-PCR but not by in situ hybridization may be related to the different sensitivities of the methods or to changes induced in the granulosa cells by the isolation procedure. It is also important to note that while follicles used for isolation of granulosa cells were assessed to be non-atretic, it is likely that follicles in the early stages of atresia were not identified. This is particularly relevant for expression of BMP2 as this gene was shown to be expressed in granulosa cells of atretic follicles by in situ hybridization.

The expression patterns for BMP2, 4 and 7 were more restricted in sheep follicles when compared with other species that have been examined to date. For instance, while expression of BMP2 mRNA was not observed in granulosa cells, theca cells, cumulus cells or oocytes of healthy follicles and was restricted to atretic follicles in the sheep ovary in situ, both the granulosa and thecal cells of non-atretic rat follicles as well as atretic follices expressed BMP2 as detected by in situ hybridization (Erickson \& Shimasaki 2003). In chickens, expression of BMP2 mRNA was detected in both the theca and granulosa of non-atretic antral follicles using RT-PCR (Onagbesan et al. 2003) while 


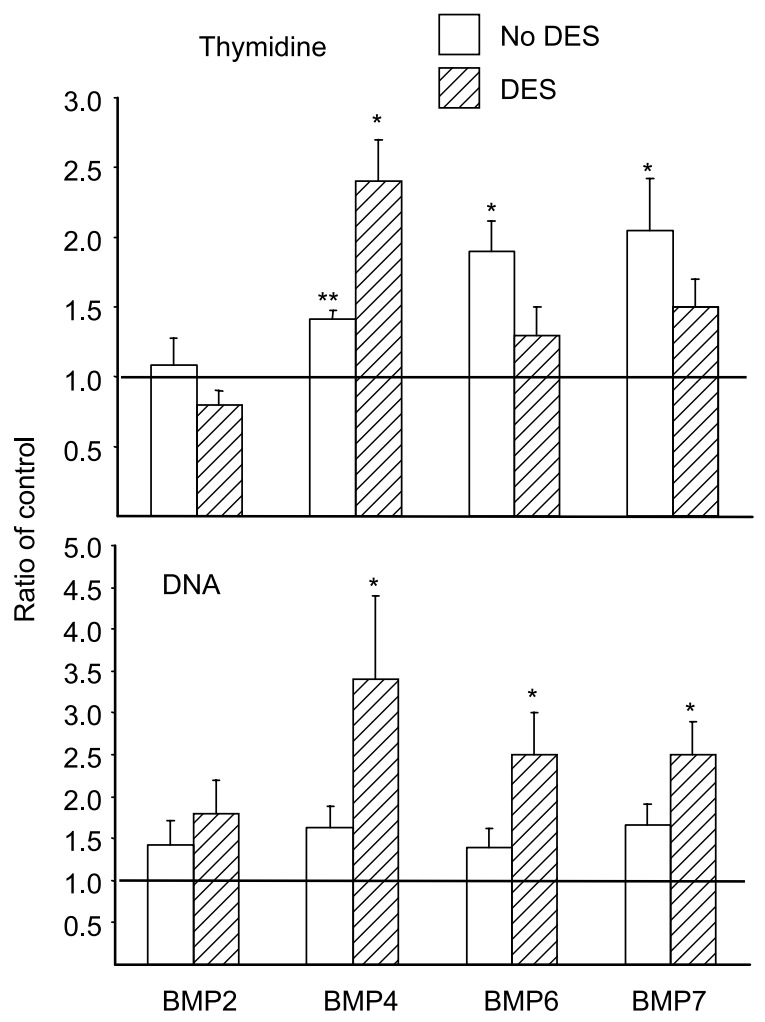

Figure 9 Effects of BMP2, 4, 6 and 7 on thymidine uptake (top panel) and DNA concentrations (bottom panel). Granulosa cells were collected from rats not treated with DES (open bar) or rats treated with DES (striped bar). Values (mean+S.E.M., $n>3$ independent pools of granulosa cells per treatment) are expressed as a ratio of the control value, which is indicated with the horizontal line at 1.0. ${ }^{*} P<0.05$, ** $P<0.01$ when compared with control values.

in cattle BMP2 protein was predominately observed in thecal cells of antral follicles with some oocytes also staining positive using immunocytochemistry (Fatehi et al. 2005). In the present study, BMP4 and 7 mRNA was not observed in granulosa cells, theca cells, cumulus cells or oocytes of non-atretic ovine follicles in situ. In contrast, both BMP4 and 7 mRNA was detected in rat thecal cells using in situ hybridization (Erickson \& Shimasaki 2003) and in both granulosa and thecal cells in chickens as detected by RT-PCR (Onagbesan et al. 2003). Moreover, both BMP4 and 7 immunoreactive proteins were detected in bovine thecal cells by immunocytochemistry (Glister et al. 2004, Fatehi et al. 2005). In the present study, BMP6 mRNA was observed only in oocytes of sheep follicles and was not observed in granulosa cells, theca cells or cumulus cells as determined by in situ hybridization, whereas in cows (Glister et al. 2004) and rats (Erickson \& Shimasaki 2003) BMP6 was detected in both the oocytes and granulosa cells.

In some instances, these findings may represent true species differences. However, there is also a possibility that the differences are due to different methodologies. One key difference between the present study and that of Glister et al. (2004) is that the bovine granulosa and thecal
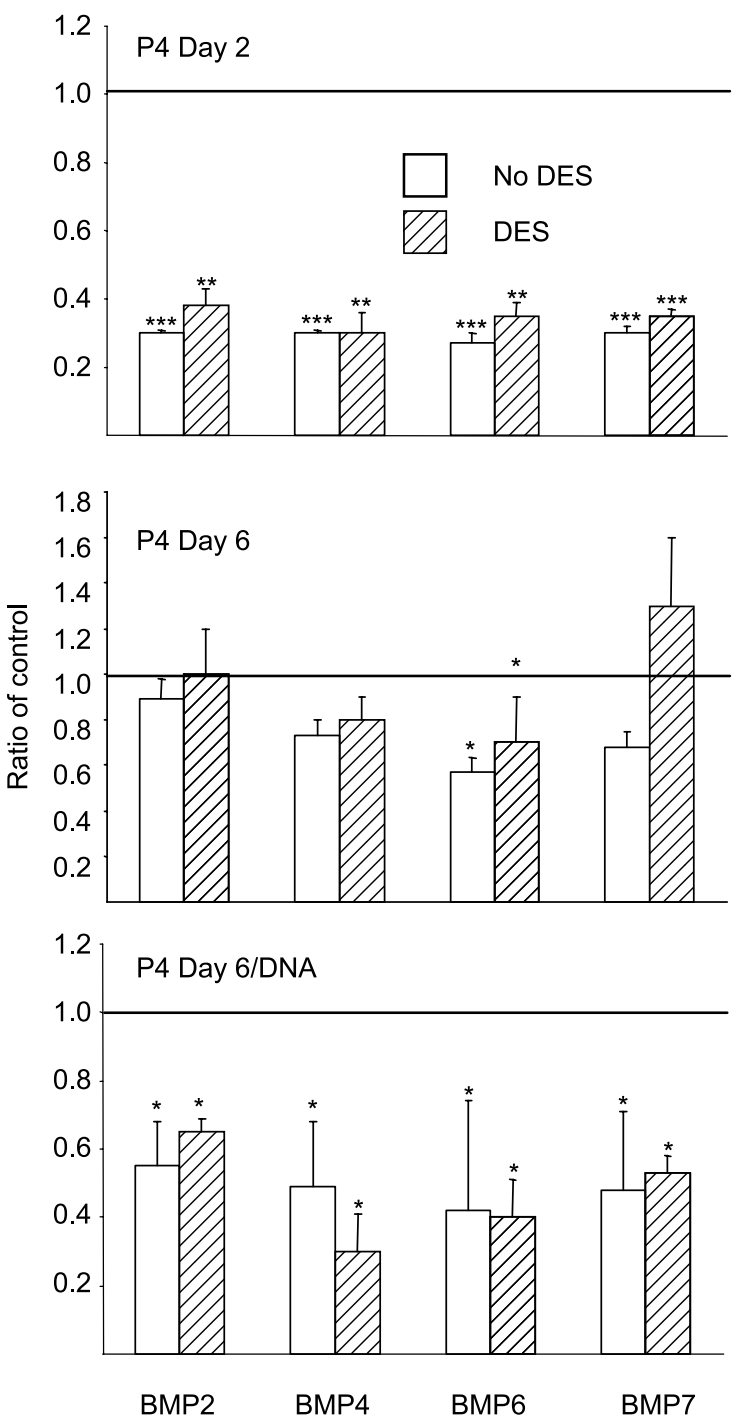

Figure 10 Effects of bone morphogenetic protein (BMP) 2, 4, 6 and 7 on concentrations of progesterone (P4) after 2 days of culture (top panel), P4 after 6 days of culture (middle panel) and P4 after 6 days of culture corrected for DNA concentration (bottom panel). Granulosa cells were collected from rats not treated with DES (open bar) or rats treated with DES (striped bar). Values (mean+S.E.M., $n>3$ independent pools of granulosa cells per treatment) are expressed as a ratio of the control value, which is indicated with the horizontal line at 1.0. ${ }^{*} P<0.05,{ }^{* *} P<0.01,{ }^{* * *} P<0.001$ when compared with control values.

cells had been cultured for 6 days before examination compared with in situ examination of ovine granulosa and theca cells at tissue recovery. Given the low level of expression detected by RT-PCR for these genes in isolated granulosa cells, it is possible that the culture conditions may have induced expression of the BMPs in bovine granulosa and theca cells.

In ovine granulosa cells, neither BMP2, 4, 6 nor 7 stimulate granulosa cell proliferation/survival. In contrast, while some differences were noted among the rat assays according to animal treatment and end measurement overall, 
BMP4, 6 and 7 all stimulated granulosa cell proliferation/ survival in rat granulosa cells and the effects of BMP2 on DNA content at the end of culture approached significance for the DES treated rat cells $(P<0.06)$. Previously, BMP4, 6 and 7 have been shown to increase cell numbers in cultures of bovine granulosa cells (Glister et al. 2004) and BMP 7 stimulated thymidine uptake and numbers of cultured granulosa cells in rats (Lee et al. 2001) and chickens (Onagbesan et al. 2003) whereas BMP4 or 6 had no effect on cell numbers in the chicken (Onagbesan et al. 2003) or thymidine incorporation of rat granulosa cells (Otsuka et al. 2001), respectively. The reasons for the differences between these findings, including the differences between the DES-treated and non-treated rats in the present study, may relate to differences in methodologies. Multiple factors, including the stage of maturation of the granulosa cells, differences in media composition such as addition of factors such as FSH and IGF-1, or differences in length of the culture period may influence the responsiveness to BMPs. In addition, determination of cell numbers/DNA content will take into account both cell mitosis and cell death, whereas measuring thymidine uptake only measures the intent for cell division. However, it is important to note that in the present study, rat and ovine granulosa cells were cultured under identical conditions suggesting that true differences between species in their responses to BMPs exist. Interestingly, the effects of BMP15 and GDF9, other TGF $\beta$ superfamily members, have also been shown to differ subtly between even the closely related species sheep and cow when tested under identical conditions in the same laboratory suggesting the roles of the BMPs may vary even between closely related species (McNatty et al. 2005b).

BMP2, 4, 6 and 7 all suppressed progesterone production. This is in agreement with the suppressive effects of the BMPs in a number of mammalian species with respect to progesterone production by granulosa cells (Shimasaki et al. 1999, Otsuka et al. 2001, Fabre et al. 2003, Glister et al. 2004, Pierre et al. 2004). In chickens, BMP4 and 7 stimulate progesterone production by granulosa cells but this difference may be related to the differing roles of progesterone in regulation of gonadotrophins between mammalian and avian species (Onagbesan et al. 2003).

Sheep with a mutation in activin receptor-like kinase 6 (Alk6, also known as BMPRIB) have increased ovulation rates (Mulsant et al. 2001, Souza et al. 2001, Wilson et al. 2001) and the Alk6 receptor is found in both oocytes and granulosa cells (Wilson et al. 2001, Souza et al. 2002). The mechanisms by which this mutation results in increased ovulation rate, including the preferred ligand for this receptor in sheep is not known. Based on the expression patterns of BMP2, 4 and 7, these proteins do not appear to be strong candidates as the preferred physiological ligands for Alk6 in sheep granulosa cells. However, BMP6, which has been shown to be able to signal through Alk6 (Juengel \& McNatty 2005), might be one of the preferred ligands regulating follicular maturation and ovulation rate through this receptor (Shimasaki et al. 2004).
However, it is important to note that BMP15 also has been shown to act through Alk6 (Moore et al. 2003). Futhermore, the BMP15 and Alk6 mutations in sheep have been shown to have synergistic effects on ovulation rate (Davis et al. 1999). Since mice lacking an active BMP6 gene show no apparent fertility phenotype (Solloway et al. 1998), the role that BMP6 plays in regulating ovarian follicular development and ovulation rate in sheep needs further clarification.

In conclusion, several members of the BMP subfamily of the TGF $\beta$ superfamily, namely BMP2, 4, 6 and 7 were shown to have similar actions in regulating ovine granulosa cells. Specifically, these proteins suppressed concentrations of progesterone secreted into the media without affecting cell number. This is consistent with a luteinization inhibition factor. However, based on their localization patterns in developing ovarian follicles, BMP6 would be the most likely candidate to play a physiological role in the local regulation of follicular growth in sheep, as mRNA encoding BMP2, 4 and 7 could not be detected by in situ hybridization in nonatretic follicles.

\section{Acknowledgements}

This research was supported by the New Zealand Foundation for Research, Science and Technology, the Royal Society of New Zealand Marsden Fund, and Ovita Limited, Dunedin, New Zealand. The authors would also like to thank Norma Hudson, Doug Jensen and Peter Smith for help with collection of tissues, Lee-Ann Still and Lynn O'Donovan for preparation of tissue sections and Derek Heath, Anne O'Connell and Lynda Whiting for technical assistance. The authors declare that there is no conflict of interest that would prejudice the impartiality of this scientific work.

\section{References}

Chang H, Brown CW \& Matzuk MM 2002 Genetic analysis of the mammalian transforming growth factor-beta superfamily. Endocrine Reviews 23 787-823.

Chen S, Liu X \& Segaloff DL 2001 Identification of an SAS (Sp1c adjacent site)-like element in the distal $5^{\prime}$-flanking region of the rat lutropin receptor gene essential for cyclic adenosine $3^{\prime}, 5^{\prime}$-monophsphate responsiveness. Endocrinology 142 2013-2021.

Davis GH, McEwan JC, Fennessy PF, Dodds KG \& Farquhar PA 1991 Evidence for the presence of a major gene influencing ovulation rate on the X chromosome of sheep. Biology of Reproduction $\mathbf{4 4}$ 620-624.

Davis GH, Dodds KG \& Bruce GD 1999 Combined effect of the inverdale and booroola prolificacy genes on ovulation rate in sheep. Proceedings of the Association for the Advancement of Animal Breeding and Genetics 13 74-77.

Di Pasquale E, Beck-Peccoz P \& Persani L 2004 Hypergonadotropic ovarian failure associated with an inherited mutation of human bone morphogenetic protein-15 (BMP15) gene. American Journal of Human Genetics 75 106-111.

Dong J, Albertini DF, Nishimori K, Kumar TR, Lu N \& Matzuk MM 1996 Growth differentiation factor-9 is required during early ovarian folliculogenesis. Nature 383 531-535. 
Dooley CA, Attia GR, Rainey WE, Moore DR \& Carr BR 2000 Bone morphogenetic protein inhibits ovarian androgen production. Journal of Clinical and Endocrinological Metabolism 85 3331-3337.

Erickson GF \& Shimasaki S 2003 The spatiotemporal expression pattern of the bone morphogenetic protein family in rat ovary cell types during the estrous cycle. Reproductive Biology and Endocrinology 19.

Fabre S, Pierre A, Pisselet C, Mulsant P, Lecerf F, Pohl J, Monget P \& Monniaux D 2003 The Booroola mutation in sheep is associated with an alteration of the bone morphogenetic protein receptor-IB functionality. Journal of Endocrinology 177 435-444.

Fatehi AN, van den Hurk R, Colenbrander B, Daemen AJ, van Tol HT, Monteiro RM, Roelen BA \& Bevers MM 2005 Expression of bone morphogenetic protein2 (BMP2), BMP4 and BMP receptors in the bovine ovary but absence of effects of BMP2 and BMP4 during IVM on bovine oocyte nuclear maturation and subsequent embryo development. Theriogenology 63 872-889.

Galloway SM, McNatty KP, Cambridge LM, Laitinen MP, Juengel JL, Jokiranta TS, McLaren RJ, Luiro K, Dodds KG, Montgomery GW et al. 2000 Mutations in an oocyte-derived growth factor gene (BMP15) cause increased ovulation rate and infertility in a dosagesensitive manner. Nature Genetics 25 279-283.

Glister C, Kemp CF \& Knight PG 2004 Bone morphogenetic protein (BMP) ligands and receptors in bovine ovarian follicle cells: actions of BMP-4, -6 and -7 on granulosa cells and differential modulation of Smad-1 phosphorylation by follistatin. Reproduction $127239-254$.

Glister C, Richards SL \& Knight PG 2005 Bone morphogenetic proteins (BMP) $-4,-6$ and -7 potently suppress basal and LH-induced androgen production by bovine theca interna cells in primary culture: could ovarian hyperandrogenic dysfunction be caused by a defect in thecal BMP signaling? Endocrinology 146 1183-1192.

Hanrahan JP, Gregan SM, Mulsant P, Mullen M, Davis GH, Powell R \& Galloway SM 2004 Mutations in the genes for oocyte-derived growth factors GDF9 and BMP15 are associated with both increased ovulation rate and sterility in Cambridge and Belclare sheep (Ovis aries). Biology of Reproduction 70 900-909.

Juengel JL \& McNatty KP 2005 The role of proteins of the transforming growth factor-beta superfamily in the intraovarian regulation of follicular development. Human Reproduction Update 11 143-160.

Juengel JL, Hudson NL, Heath DA, Smith P, Reader KL, Lawrence SB, O'Connell AR, Laitinen MP, Cranfield M, Groome NP et al. 2002 Growth differentiation factor 9 and bone morphogenetic protein 15 are essential for ovarian follicular development in sheep. Biology of Reproduction 67 1777-1789.

Juengel JL, Hudson NL, Whiting L \& McNatty KP 2004 Effects of immunization against bone morphogenetic protein 15 and growth differentiation factor 9 on ovulation rate, fertilization, and pregnancy in ewes. Biology of Reproduction 70 557-561.

Kaivo-Oja N, Bondestam J, Kamarainen M, Koskimies J, Vitt U, Cranfield M, Vuojolainen K, Kallio JP, Olkkonen VM, Hayashi M et al. 2003 Growth differentiation factor-9 induces Smad2 activation and inhibin B production in cultured human granulosaluteal cells. Journal of Clinical and Endocrinological Metabolism $88755-762$.

Knight PG \& Glister C 2003 Local roles of TGF-beta superfamily members in the control of ovarian follicle development. Animal Reproduction Science 78 165-183.

Lee WS, Otsuka F, Moore RK \& Shimasaki S 2001 Effect of bone morphogenetic protein-7 on folliculogenesis and ovulation in the rat. Biology of Reproduction 65 994-999.

Lee WS, Yoon SJ, Yoon TK, Cha KY, Lee SH, Shimasaki S, Lee S \& Lee KA 2004 Effects of bone morphogenetic protein-7 (BMP-7) on primordial follicular growth in the mouse ovary. Molecular and Reproductive Development 69 159-163.

Lun S, Smith P, Lundy T, O'Connell A, Hudson N \& McNatty KP 1998 Steroid contents of and steroidogenesis in vitro by the developing gonad and mesonephros around sexual differentiation in fetal sheep. Journal of Reproduction and Fertility 114 131-139.
Lundy T, Smith P, O'Connell A, Hudson NL \& McNatty KP 1999 Populations of granulosa cells in small follicles of the sheep ovary. Journal of Reproduction and Fertility 115 251-262.

McNatty KP, Hudson NL, Collins F, Fisher M, Heath DA \& Henderson KM 1989 Effects of oestradiol-17b, progesterone or bovine follicular fluid on the plasma concentration on FSH and $\mathrm{LH}$ in ovariectomized Booroola ewes which were homozygous carriers or non-carriers of a fecundity gene. Journal of Reproduction and Fertility 87 573-585.

McNatty KP, Juengel JL, Wilson T, Galloway SM, Davis GH, Hudson NL, Moeller CL, Cranfield M, Reader KL, Laitinen MP et al. 2003 Oocyte-derived growth factors and ovulation rate in sheep. Reproduction Supplement 61 339-351.

McNatty KP, Galloway SM, Wilson T, Smith P, Hudson NL, O'Connell A, Bibby AH, Heath DA, Davis GH, Hanrahan JP et al. 2005a Physiological effects of major genes affecting ovulation rate in sheep. Genetics, Selection, Evolution 37 (Supplement 1) S25-S38.

McNatty KP, Juengel JL, Reader KL, Lun S, Myllymaa S, Lawrence SB, Western A, Meerasahib MF, Mottershead DG, Groome NP et al. $2005 b$ Bone morphogenetic protein 15 and growth differentiation factor 9 co-operate to regulate granulosa cell function in ruminants. Reproduction 129 481-487.

Matzuk MM 2000 Revelations of ovarian follicle biology from gene knockout mice. Molecular and Cellular Endocrinology 163 $61-66$.

Moore RK, Otsuka F \& Shimasaki S 2003 Molecular basis of bone morphogenetic protein-15 signaling in granulosa cells. Journal of Biological Chemistry 278 304-310.

Mulsant P, Lecerf F, Fabre S, Schibler L, Monget P, Lanneluc I, Pisselet C, Riquet J, Monniaux D, Callebaut I et al. 2001 Mutation in bone morphogenetic protein receptor-IB is associated with increased ovulation rate in Booroola Merino ewes. PNAS 98 5104-5109.

Nilsson EE \& Skinner MK 2003 Bone morphogenetic protein-4 acts as an ovarian follicle survival factor and promotes primordial follicle development. Biology of Reproduction 69 1265-1272.

Onagbesan OM, Bruggeman V, Van As P, Tona K, Williams J \& Decuypere E 2003 BMPs and BMPRs in chicken ovary and effects of BMP-4 and -7 on granulosa cell proliferation and progesterone production in vitro. American Journal of Physiology and Endocrinological Metabolism 285 E973-E983.

Otsuka F, Moore RK \& Shimasaki S 2001 Biological function and cellular mechanism of bone morphogenetic protein-6 in the ovary. Journal of Biological Chemistry 276 32889-32895.

Pierre A, Pisselet C, Dupont J, Mandon-Pepin B, Monniaux D, Monget P \& Fabre S 2004 Molecular basis of bone morphogenetic protein- 4 inhibitory action on progesterone secretion by ovine granulosa cells. Journal of Molecular Endocrinology 33 805-817.

Shimasaki S, Zachow RJ, Li D, Kim H, lemura S, Ueno N, Sampath K, Chang RJ \& Erickson GF 1999 A functional bone morphogenetic protein system in the ovary. PNAS 96 7282-7287.

Shimasaki S, Moore RK, Otsuka F \& Erickson GF 2004 The bone morphogenetic protein system in mammalian reproduction. Endocrine Reviews 25 72-101.

Solloway MJ, Dudley AT, Bikoff EK, Lyons KM, Hogan BL \& Robertson EJ 1998 Mice lacking Bmp6 function. Developmental Genetics 22 321-339.

Souza CJ, MacDougall C, Campbell BK, McNeilly AS \& Baird DT 2001 The Booroola $(\mathrm{FecB})$ phenotype is associated with a mutation in the bone morphogenetic receptor type 1 B (BMPR1B) gene. Journal of Endocrinology 169 R1-R6.

Souza CJ, Campbell BK, McNeilly AS \& Baird DT 2002 Effect of bone morphogenetic protein 2 (BMP2) on oestradiol and inhibin A production by sheep granulosa cells, and localization of BMP receptors in the ovary by immunohistochemistry. Reproduction $123363-369$

Tisdall DJ, Hudson N, Smith P \& McNatty KP 1994 Localization of ovine follistatin and alpha and beta A inhibin mRNA in the sheep ovary during the oestrous cycle. Journal of Molecular Endocrinology 12 181-193. 
Tisdall DJ, Fidler AE, Smith P, Quirke LD, Stent VC, Heath DA \& McNatty KP 1999 Stem cell factor and c-kit gene expression and protein localization in the sheep ovary during fetal development. Journal of Reproduction and Fertility 116 277-291.

Wilson T, Wu XY, Juengel JL, Ross IK, Lumsden JM, Lord EA, Dodds KG, Walling GA, McEwan JC, O'Connell AR et al. 2001 Highly prolific Booroola sheep have a mutation in the intracellular kinase domain of bone morphogenetic protein IB receptor (ALK-6) that is expressed in both oocytes and granulosa cells. Biology of Reproduction 64 1225-1235.
Yan C, Wang P, DeMayo J, DeMayo FJ, Elvin JA, Carino C, Prasad SV, Skinner SS, Dunbar BS, Dube JL et al. 2001 Synergistic roles of bone morphogenetic protein 15 and growth differentiation factor 9 in ovarian function. Molecular Endocrinology 15 854-866.

Received 13 September 2005

First decision 17 October 2005

Revised manuscript received 20 November 2005

Accepted 28 November 2005 